$10.2478 /$ cer-2018-0010

ANNA MATYSEK-JECDRYCH*

\title{
Institutional Arrangement for Macroproprudential Policy - On Differences Across the EU Countries
}

\begin{abstract}
There is a growing consensus among both economists-academics and policymakers that there was at least one missing element of the financial safety net during the Global Financial Crisis. This element, which will probably improve financial stability (or protect against financial instability), is the macroprudential orientation in regulatory and supervisory frameworks. The main scope of the paper is the institutional dimensions of macroprudential policy.

The principal purpose of the paper is to identify and assess, on a comparative, cross-EU-country basis, existing practices and developments in structuring a new dimension of the financial stability policy, i.e., a macroprudential one.

The paper builds on existing theoretical considerations and the author's own empirical survey of country practices in applying a macroprudential framework. A comparative, cross-country analysis and a comparison of different sub-indices and overall index values are the basis for verifying hypotheses and empirically disentangling the institutional differences between macroprudential policy regimes in European Union countries.

The paper sheds light on recent trends in macroprudential policy governance and qualitative aspects (democratic accountability and transparency), with special attention to the position of a central bank across the European Union countries. The conducted research is a basis for constructing ratings of macroprudential authority accountability and transparency across the EU countries, which gives an indication of the overall quality of the institutional arrangements.
\end{abstract}

Keywords: central banking, financial stability, macroprudential policy, systemic risk

JEL: E58, E61, G18, G28, H12

* Ph.D., Assistant Professor at the Poznań University of Economics and Business, Department of the International Competitiveness, Poznan, Poland, e-mail: anna.jedrych@ue.poznan.pl 


\section{Introduction}

The genesis and mechanisms behind the global financial crisis still seem to be a subject of controversy. Most researchers agree that the nature of the crisis was complex, but they concentrate on different factors while searching for the origin of the crisis: financial, economic, political, legal, psychological as well as cultural ones (Obstfeld \& Rogoff 2009; Taylor 2009; Merrouche \& Nier 2010; Roubini \& Mihm 2010; Barth et al. 2012). Most observers have also argued that the crisis was unpredictable and extremely severe, largely because the regulatory framework in place prior to the crisis was microprudential in nature (Brunnermeier et al. 2009; Hanson et al. 2011, pp. 3-28). The global financial crisis exposed the weaknesses of this microprudential approach as well as the pre-crisis regulatory and supervisory structure as such (which was aptly described by Schinasi (2010) as a 'patchwork of rules of the game and regulatory and supervisory principles').

In response to the crisis, different countries as well as international bodies are evaluating and, in consequence, implementing reforms aimed at reshaping the financial safety net. Recent experience has demonstrated that financial stability (in contrast to price stability) and macroprudential policy, as an essential contributor to its delivery, should be given higher priority compared to the past. While macroprudential policy tools had been in use in a number of countries well before the global financial crisis, the creation of a dedicated macroprudential policy framework seems to have been prompted by the crisis experience.

The extensive range of institutional arrangements being adopted across countries suggests that there is no 'one-size-fits-all' approach (Nier et al. 2011). Nonetheless, experience highlights - and this paper documents - a number of elements that have been found useful for macroprudential policy structuring as well as macroprudential policy effectiveness. The topic of an adequate institutional framework for macroprudential policy is essential, although it still lacks a strong theoretical background. It seems that now is a good moment to diagnose the situation and draw conclusions in the form of stylized facts (Borio 2010; Nier et al. 2011) or a comparative study based on primary data (Egawa, Otani \& Sakiyama 2015).

As part of the research conducted, three research hypotheses were formulated and subsequently verified in this paper.

H1: To be effective, institutional arrangements for macroprudential policy need to ensure a policymaker's ability and willingness to act, firstly, by including a clear and formal mandate.

A clear and formal (regulated by law) mandate in relation to the macroprudential policy seems to be the sine qua non condition for effective policy. This has been stressed by most recommendations formulated by international institutions (IMF 2011; IMF-FSB-BIS 2016), pan-European organizations (ESRB 2011) and researchers (Nier et al. 2011; Borio 2014). 
H2: Structuring the macroprudential policy should be accompanied by creating mechanisms of accountability and transparency which can establish legitimacy and create a commitment to take action.

Expectations toward transparency and using communication tools force the macroprudential authority - by analogy the central bank - to make a choice between discretionary activities and adopting specific rules (Kydland \& Prescott 1977). When deciding on the optimum transparency level, one should pay attention to the trade-off between opportunities being a consequence of managing expectations and threats resulting from over-transparency.

H3: Central bank-based macroprudential policy arrangements are more stable and homologous, the consequence of applying a rational analogy to the well-known institutional design of effective monetary policy.

The hypotheses are verified by comparing the level of objective accountability de jure and objective accountability de facto (H1), by analyzing the level of transparency index as well as by comparing the level of sub-indices in relation to two separate models of macroprudential authority, i.e., central bank-based and collegial body-based.

The principal purpose of the paper is to identify and assess, on a comparative, cross-EU-country basis, existing practices and developments in structuring new dimension of financial stability policy, i.e., a macroprudential one. In this way, the paper aims to contribute to the ongoing debate on institutional arrangements for macroprudential policy.

The paper is organized as follows. The introduction clarifies the motivation for writing the paper, its purpose and structure. The research methodology is described in the next section. Then, the following sections of this paper are devoted to the presentation of the empirical results. Finally, in the last part of the paper, we conclude with a discussion on policy implications.

\section{Research methodology}

The research on institutional arrangements for macroprudential policy was conducted on a sample of twenty-eight macroprudential authorities from the European Union member states between November 2016 and February 2017. Seven representatives of macroprudential authority in the EU countries did not respond (i.e. Austria, Bulgaria, Croatia, France, Malta, the Netherlands, and Spain). Macroprudential authorities are represented by different institutional bodies in different countries: central banks, financial supervisory authorities or separate institutions created for the purpose of executing macroprudential policy. The empirical analysis employs information collected via a questionnaire from twenty-one EU coun- 
tries. The countries differ in terms of institutional framework, level of economic development as well as size and level of development of the financial sector. Nevertheless, this area is still the most integrated region in the world.

When constructing the index of institutional arrangements of macroprudential policy, the main goal was to strive to offer a measure which would facilitate a comparison of individual countries solutions. The following factors employed in the process had a significant impact on the constituent components of the index:

- The experience of the researchers in the field of institutional, qualitative aspects of central banks and financial regulators policy (Eijffinger \& Hoeberichts 2000, pp. 73-96; Cukierman 2001; De Haan et al. 2004, pp. 775-794; Masciandaro et al. 2008, pp. 833-848; Blinder et al. 2009, pp. 910-945, Horváth \& Vaško 2016, pp. 45-56).

- Striving to review hypotheses (hence, e.g., the separation of objective accountability into de jure and de facto).

- The degree of the advancement of research on macroprudential policy, its effectiveness, institutional framework and tools (Milne 2009, pp. 608-629; Hanson et al. 2011, pp. 3-28; Galati \& Moessner 2013, pp. 846-878; Borio 2014, pp. 79-85).

The institutional arrangements measure for macroprudential policy, developed by the author for the purposes of this research, is comprised of the following sub-indices:

The first stage of the study (identifying the macroprudential authority model):

- The composition of the macroprudential authority (who is responsible for the macroprudential policy?).

The second stage of the study (overall accountability index):

- Objective accountability (accountability for what? As governed by law versus by moral obligation, i.e., formal versus informal objective accountability).

- Subjective accountability for financial stability (accountability before whom?).

- Transparency as a demonstration of subjective accountability (accountability using what communication tools and how often?).

When constructing the indices (cf. Table 1), all components were assigned 0 points (the component does not apply) or 1 point (the component applies). Thus, individual components were not differentiated for their varying importance, mainly due to the fact that the matter of institutional arrangement for macroprudential policy is still a topic of lively discussion and controversy.

The paper builds on the author's own survey of different countries' practices in applying macroprudential policy framework. A total of 23 different criteria are identified to assess and compare the macroprudential institutional arrangement across the EU countries. 
Table 1. Construction of indices for macroprudential policy arrangement

\begin{tabular}{|c|}
\hline COMPOSITION OF MACROPRUDENTIAL AUTHORITY \\
\hline $\begin{array}{l}\text { Is there a formal body/institution responsible for macroprudential policy in your country? } \\
\text { What is the composition of the macroprudential policy authority (MPA): } \\
\text { - single body } \\
\text { collegial body } \\
\text { - multiple body } \\
\text { - decision-making in the macroprudential policy? } \\
\text { - calibration of instruments of the macroprudential policy? } \\
\text { analysis of systemic risk? }\end{array}$ \\
\hline OVERALL ACCOUNTABILITY INDEX (from 0 to 17) \\
\hline ACCOUNTABILITY FOR WHAT de jure? (from 0 to 3) \\
\hline $\begin{array}{l}\text { Does the MPA have an explicit objective for macroprudential policy (objective documented } \\
\text { in law or in another formal way)? } \\
\text { Is this objective quantifiable (or partly quantifiable)? } \\
\text { Are there explicit secondary objectives for macroprudential policy? }\end{array}$ \\
\hline ACCOUNTABILITY FOR WHAT de facto? (from 0 to 2) \\
\hline $\begin{array}{l}\text { Does the MPA have an implicit objective for macroprudential policy (an objective that MBA } \\
\text { feels responsible for)? } \\
\text { Is this objective quantifiable (or partly quantifiable)? }\end{array}$ \\
\hline ACCOUNTABLE HOW? (from 0 to 8 ) \\
\hline $\begin{array}{l}\text { Does the MPA make a regular assessment of systemic risk? } \\
\text { Is the outcome of this assessment published (e.g. in a Financial Stability Report, or another } \\
\text { special publication)? If yes, how frequently? } \\
\text { Does the MPA organize press conferences related to systemic risk (ex-post approach, } \\
\text { explaining past movements)? } \\
\text { Does the MPA organize press conferences related to systemic risk (ex-ante approach, } \\
\text { explaining future movements)? } \\
\text { Does the MPA publish press releases? } \\
\text { Does the MPA publish meeting records? } \\
\text { Does the MPA make any statement of future movements in relation to macroprudential policy } \\
\text { (ex-ante approach)? } \\
\text { Are the communication tools required by law? }\end{array}$ \\
\hline ACCOUNTABILITY TO WHOM? (from 0 to 4) \\
\hline $\begin{array}{l}\text { Is the MPA accountable to another party in relation to macroprudential policy actions? Is the } \\
\text { MPA monitored by another party (e.g. Parliament)? } \\
\text { Does the MPA have to report to the accountee on macroprudential policy decisions (besides } \\
\text { annual reports)? } \\
\text { Does the government/ Parliament have the right to give to MPA instructions related } \\
\text { to macroprudential policy? } \\
\text { Is there some kind of procedure for the implementation of an override mechanism? }\end{array}$ \\
\hline
\end{tabular}

Source: own research. 


\section{Composition of the macroprudential authority - a comparative analysis of EU countries}

The analysis of institutional arrangement in macroprudential policy should probably begin by answering the question whether there is or is not a formal authority which is responsible for macroprudential policy. There was a clear need to identify or establish an authority that oversees systemic risk and decides about policy actions. Such an authority could be an institution (existing or a new one, e.g., the central bank, a financial regulator) or a body (e.g. a committee, a council). Institutional arrangements for macroprudential policy vary among jurisdictions; nevertheless, two dominant models can be identified (cf. Table 2).

In the European Union, there are two dominant models in relation to the macroprudential policy: institutional arrangements which are central bank-based (11 out of 21 analyzed cases) and collegial body-based (8 out of 21 analyzed cases). In two other cases, in Finland and Sweden, the financial supervisory authority also plays the role of macroprudential authority, while in Italy (a multiple body as a macroprudential authority existed in Italy while the research was conducted), intensive work was underway aimed at establishing a collegial body-based model no later than September 2017.

Table 2. Macroprudential authority models across EU countries

\begin{tabular}{|c|c|c|}
\hline $\begin{array}{c}\text { Central bank } \\
\text { as a macroprudential } \\
\text { authority }\end{array}$ & $\begin{array}{l}\text { Financial supervisory authority } \\
\text { as a macroprudential authority }\end{array}$ & $\begin{array}{l}\text { Collegial body } \\
\text { as a macroprudential authority }\end{array}$ \\
\hline $\begin{array}{l}\text { Belgium } \\
\text { Cyprus } \\
\text { Czech Republic } \\
\text { Estonia } \\
\text { Greece } \\
\text { Hungary } \\
\text { Ireland } \\
\text { Latvia } \\
\text { Lithuania } \\
\text { Portugal } \\
\text { Slovakia }\end{array}$ & $\begin{array}{l}\text { Finland } \\
\text { Sweden }\end{array}$ & $\begin{array}{l}\text { Denmark } \\
\text { Germany } \\
\text { Italy* } \\
\text { Luxembourg } \\
\text { Poland } \\
\text { Romania } \\
\text { Slovenia } \\
\text { United Kingdom (location in CB) }\end{array}$ \\
\hline
\end{tabular}

*In 2017, a collegial body (Macroprudential Policy Committee) as a macroprudential authority was to be established.

Source: own calculations based on own research.

Existing arrangements in relation to collegial bodies vary across countries. This body typically involves a central bank (board or governor), which is the case of all analyzed countries, a financial supervisory authority (or sectoral supervisory authority), as well as government members. Differences appear in relation to the last member. In some countries, the Ministry of Finance participates in the colle- 
gial body as a non-voting member (Slovenia and the United Kingdom), in others, this person is a voting member (Poland) or even a chair member (Germany). Such involvement can be perceived as useful to create political legitimacy for macroprudential policy on the one hand, but it might create political economy risks, on the other hand. To mitigate the second problem, e.g., in Germany, the central bank veto power was introduced in the committee.

The two basic models of macroprudential policy institutional arrangements differ in relation to the value and descriptive statistics of proposed institutional arrangements index (cf. Table 3). The average value of the index is higher in the case of the central bank-based model (8.77 points compared to 7.83 points). According to the methodology applied in this survey, the higher value of the index can be interpreted as a higher level of formality in designing institutional arrangements.

Table 3. Descriptive statistics of institutional arrangement index for macroprudential authorities

\begin{tabular}{|l|c|c|c|}
\hline $\begin{array}{c}\text { Macroprudential } \\
\text { authority model }\end{array}$ & $\begin{array}{c}\text { Mean value } \\
\text { (\% of max value) }\end{array}$ & Standard deviation & $\begin{array}{c}\text { Variation } \\
\text { coefficient }\end{array}$ \\
\hline Central bank-based & $\begin{array}{c}8.77 \\
(58.46 \%)\end{array}$ & 2.20 & $25.13 \%$ \\
\hline Collegial body-based & $\begin{array}{c}7.83 \\
(52.21 \%)\end{array}$ & 2.78 & $35.58 \%$ \\
\hline
\end{tabular}

Source: own calculations based on own research.

The other discrepancy between the two identified institutional models of macroprudential authority relates to the lower level of relative variation of institutional solutions in the case of the central bank-based model (measured both by standard deviation -2.20 compared to 2.78 and variation coefficient $-25.13 \%$ compared to $35.58 \%$ ).

\section{De jure versus de facto objective accountability of a macroprudential authority}

An effective macroprudential policy needs to be accompanied by providing the relevant authorities with a clear, formal mandate, a well-defined objective of the policy as well as adequate powers. The institutional arrangements should, therefore, be designed to foster both ability and willingness to act.

In most of the analyzed countries, the macroprudential authority has an explicit objective for macroprudential policy (this objective is documented in law), and there are only two cases with informal (implicite) accountability for macroprudential policy (Finland and Latvia). 
The specific dimensions of the index of objective accountability are defined through detailed constituent components. And so, the de jure objective accountability index is determined by three detailed variables (formal responsibility for macroprudential policy, formal and quantifiable, at least partly quantifiable objective of macroprudential policy, as well as the existence of secondary, clarifying objectives for macroprudential policy). The value of de jure accountability index varies from 0 (lack of $d e$ jure accountability) to 3 (highly formalized accountability for macroprudential policy). The results of this sub-index for 22 European countries are presented in Table 4.

Table 4. The formalization level in macroprudential policy arrangement

\begin{tabular}{|c|l|}
\hline $\begin{array}{c}\text { De jure objective } \\
\text { accountability index }\end{array}$ & \multicolumn{1}{c|}{ Countries } \\
\hline 3 & Denmark, Ireland, Italy, Luxembourg, Slovenia \\
\hline 2 & $\begin{array}{l}\text { Cyprus, Czech Republic, Estonia, Germany, Greece, Hungary, } \\
\text { Lithuania, Poland, Portugal, Slovakia, Sweden, the United Kingdom }\end{array}$ \\
\hline 1 & Belgium, Germany, Romania, \\
\hline 0 & Finland, Latvia \\
\hline
\end{tabular}

Source: own research.

The value of the de jure objective accountability index varies across the European Union countries from 3 (Denmark, Ireland, Italy, Luxembourg, Slovenia) to 0 (Finland and Latvia). However, it seems that the global financial crisis was reflected in the tendency to increase the clear formulation and formalization of the macroprudential policy responsibility. This may predominantly result from the growing expectations, both in-crisis and post-crisis, concerning efforts to stabilize the financial system by reducing the systemic risk.

The formal objective of the macroprudential policy was defined in a variety of ways in legal regulations governing the operations of specific macroprudential authorities, and it should be highlighted that a great deal of caution and ambiguity was employed while defining this objective. Examples of the objective are the following:

- (...) to contribute to the safeguarding of the stability of the financial system as a whole-Cyprus,

- (...) to promote the stability of the financial system as a whole by enhancing the resistance of the system to shocks and by reducing the accumulation of systemic risks - Estonia,

- (...) to mitigate systemic risk, which is the risk of a disruption to the provision of financial services, caused by an impairment of all or parts of the financial system, with serious negative consequences for the real economy - Ireland,

- (...) to strengthen the resilience of the financial system in the event of materialization of systemic risk, and, in consequence, to support the long-term and sustainable economic growth of the country - Poland,

- (...) to identify, monitor, and take action to remove or reduce risks that threaten the resilience of the UK financial system as a whole - the United Kingdom. 


\section{How transparent are macroprudential authorities across Europe?}

It is not an easy task to define the optimal level of transparency in relation to the macroprudential authority (cf. Walsh 2007). Besides, transparency has at least five different dimensions, which Geraats (2002) identifies as political, procedural, economic, operational and policy. These correspond to transparency about objectives, the decision-making process, the forecasts and models used in the analysis, communication about the instruments settings and about the policy actions.

Significant differences in the transparency index values within the sample of macroprudential authorities across the EU can be observed (Figure 1). Although none of the macroprudential authority disclosed the minimum value (which is 0 according to the methodology), in one case (i.e. Slovenia), its value was as low as 2 points on a scale from 0 to 8 . In contrast to this case, two countries achieved the maximum score for transparency level, in line with the methodology employed in the survey (i.e. Sweden and the United Kingdom).

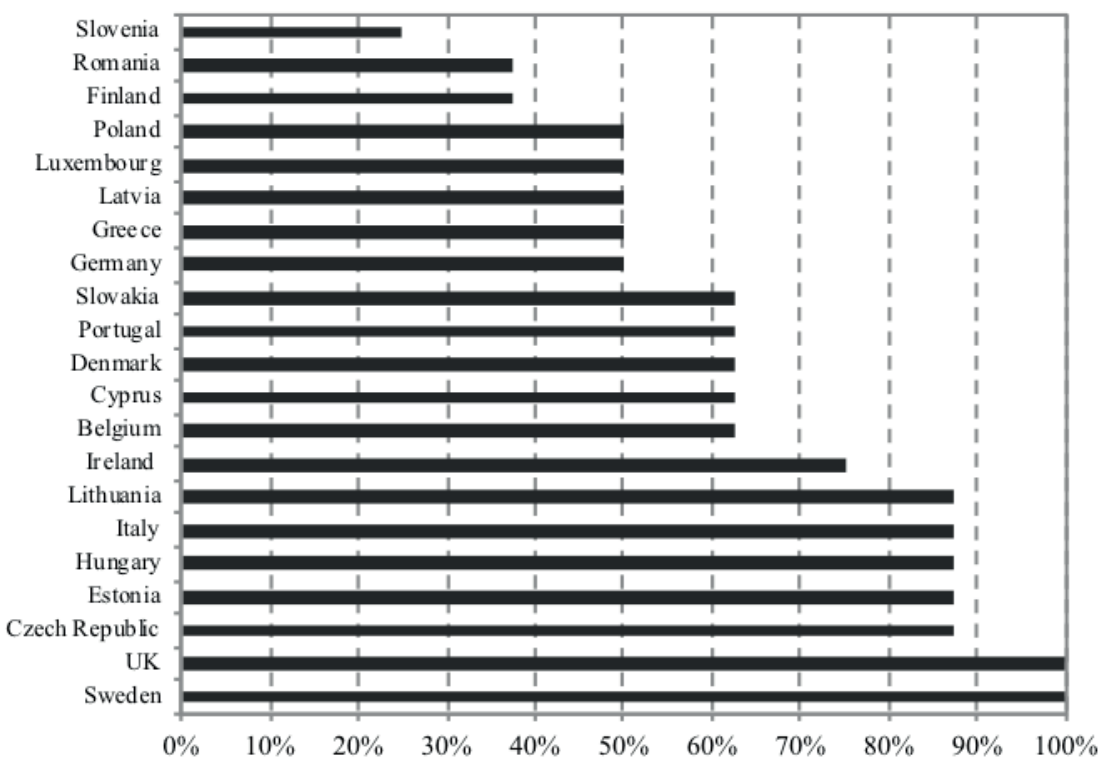

Figure 1. Transparency index of the EU countries' macroprudential authorities Source: own calculations based on own research.

Undoubtedly, these results are only a point of departure for further studies which should strive to (among others) review how a high or low level of transparency of the macroprudential authority is correlated with the effectiveness of its policy. Related studies conducted so far regards central bank financial stability policy (BIS 1998; Blinder et al. 2001; Horváth \& Vaško 2012) indicate a pattern 
which suggests that a higher transparency of efforts undertaken by central banks may contribute to fewer financial crises as well as helping to reduce their scale. Since the objective of both macroprudential policy and financial stability policy seem to be equal (at least in the long term), we might use these results as a good starting-point of both the theoretical discussion and empirical studies.

The two identified models of macroprudential policy regimes differ in relation to the value and descriptive statistics used in researching the transparency index (cf. Table 5). The average value of the index is much higher in the case of the central bank-based model (5.54 points, which is close to $70 \%$ of the maximum value of the index, compared to 4.50 points). According to the methodology applied in this survey, the higher value of the index can be interpreted as a higher level of transparency regards macroprudential policy.

Table 5. Descriptive statistics of transparency index

\begin{tabular}{|l|c|c|c|}
\hline $\begin{array}{c}\text { Macroprudential } \\
\text { authority model }\end{array}$ & $\begin{array}{c}\text { Mean value } \\
\text { (\% of max value) }\end{array}$ & Standard deviation & Variation coefficient \\
\hline Central bank-based & $\begin{array}{c}5.54 \\
(69.23 \%)\end{array}$ & 1.39 & $25.12 \%$ \\
\hline Collegial body-based & $\begin{array}{c}4.50 \\
(56.25 \%)\end{array}$ & 1.97 & $43.89 \%$ \\
\hline
\end{tabular}

Source: own calculations based on own research.

The other discrepancy between the two identified institutional models of macroprudential authority relates to the lower level of relative variation of institutional solutions in the case of the central bank-based model (as measured by standard deviation - 1.39 compared to 1.97 and largely also by variation coefficient $-25.12 \%$ compared to $43.89 \%$ ).

\section{Conclusions}

Putting in place a macroprudential institutional framework seems to be the biggest lesson from the Global Financial Crisis that has been embedded in policy. There is an important argument in favor of introducing some form of explicit statutory framework for macroprudential policy (e.g. clear objective, powers, responsibilities, accountability mechanisms as well as a clear decision-making process). However, the present level of knowledge and experience still seem to be too low to create inflexible and highly complex structures.

Although the institutional arrangement is inevitably shaped by country-specific circumstances, some general tendencies can be identified, and the research conducted on the sample of twenty-one European Union countries' macroprudential authorities has led to the development of general conclusions as follows: 
- In the EU countries, including CEE countries, a process of formalizing the objective of the macroprudential policy, as well as institutional arrangements for this kind of policy, can be observed; nevertheless, this process is coupled by the heterogenic manner of defining this objective (imprecise, ambiguous and general definitions prevail). What could be recommended in this aspect is to increase the level of precision and measurability of the main objective for the macroprudential authority. Too general a construction of objectives may cause operational problems and is likely to be the foundation for losing responsibility.

- The outcome of the study suggests that the one-size-fits-all rule should not be employed when developing institutional arrangements concerning the macroprudential policy. At the same time, it is important to draw on the experiences of solutions concerning other policy objectives, e.g., price stability (specifically in relation to the transparency of the macroprudential authority, a 'rational analogy' to monetary policy is observed).

- Strengthening democratic accountability for the macroprudential authority (by increasing both objective and subjective accountability as well as transparency level) may be considered as a pre-requisite for structuring a highly effective macroprudential policy.

The continuation of this research will deliver answers to some important governance issues which merit special attention: first, what, if any, is the degree of macroprudential authority insulation from the political cycle; second, what are the determinants of designing institutional arrangements for the macroprudential policy; and third, which elements of institutional arrangements are crucial for enhancing macroprudential policy effectiveness.

\section{References}

Barth, J.R., Caprio, G. \& Levine, R. (2012), Guardians of Finance: Making Regulators Work for Us, MIT Press.

Blinder, A.S., Ehrmann, M., Fratzscher, M., de Haan, J. \& Jansen, D.-J. (2009), Central Bank Communication and Monetary Policy: A Survey of Theory and Evidence, 'Journal of Economic Literature', Vol. 46, No. 4, DOI: http://dx.doi.org/10.1257/jel.46.4.910

Borio, C. (2010), Implementing a macroprudential framework. Blending boldness and realism, Bank for International Settlements, 22 July.

Borio, C. (2014), (Too) great expectations for macro-prudential? ‘Central Banking Journal', Vol. 41, No. 2.

Brunnermeier, M., Crockett, A., Goodhart, C., Persaud, A.D. \& Shin, H. (2009), The Fundamental Principles of Financial Regulation, 'Geneva Reports on the World Economy', No. 11.

Cukierman, A. (2001), Accountability, Credibility, Transparency and Stabilization Policy in the Eurosystem, [in]: Ch. Wyplosz (ed.). The Impact of EMU on Europe and the Developing Countries, Oxford University Press, Oxford. 
De Haan, J., Amtenbrink F., \& Waller, S. (2004), The Transparency and Credibility of the European Central Bank, 'Journal of Common Market Studies', No. 42.

Egawa, E., Otani A. \& Sakiyama T. (2015), What determines institutional arrangement for macroprudential policy? IMES Discussion Paper Series, 2015-E-3, June.

Eijffinger, S.C.W. \& Hoeberichts, M.M. (2000), Central Bank Accountability and Transparency. Theory and Some Evidence, 'International Finance', Vol. 5, No. 1, DOI: http://dx.doi.org/10.1111/ $1468-2362.00088$

ESRB (2011), Recommendations of the European Systemic Risk Board of 22 December 2011 on the macro-prudential mandate of national authorities (ESRB/2011/3), European Systemic Risk Board, Frankfurt am Main.

Galati, G. \& Moessner, R. (2013), Macroprudential policy - a literature review, 'Journal of Economic Surveys', Vol. 27, No. 5, DOI: http://dx.doi.org/10.1111/j.1467-6419.2012.00729.x

Geraats, P.M. (2002), Central Bank Transparency, 'Economic Journal', No. 112 (November), DOI: http://dx.doi.org/10.1111/1468-097.00082

Hanson, S.G., Kashyap A.K. \& Stein, J.C. (2011), A Macroprudential Approach to Financial Regulation, "Journal of Economic Perspectives", Vol. 25, No. 1, DOI: http://dx.doi.org/10.1257/ jep.25.1.3

Horváth, R. \& Vaško, D. (2016), Central bank transparency and financial stability, 'Journal of Financial Stability', No. 22, DOI: http://dx.doi.org/10.1016/j.jfs.2015.12.003

IMF (2011), Macroprudential Policy: An Organizing Framework, International Monetary Fund, Washington D.C., March 14.

IMF-FSB-BIS (2016), Elements of Effective Macroprudential Policies. Lessons from International Experience, International Monetary Funds, Financial Stability Board, Bank for International Settlement, Washington D.C., 31 August.

Kydland, F.E., \& Prescott, E.C. (1977), Rules rather than discretion: the inconsistency of optimal plans, 'Journal of Political Economy', Vol. 85, No. 3, DOI: http://dx.doi.org/10.1086/260580.

Masciandaro, D., Quintyn, M. \& Taylor, M. (2008), Inside and outside the central bank: Independence and accountability in financial supervision. Trends and determinants, 'European Journal of Political Economy', No. 24.

Merrouche, O. \& Nier, E. (2010), What Caused the Global Financial Crisis? Evidence on the Drivers of Financial Imbalances 1999-2007, 'IMF Working Paper', No. 265.

Milne, A. (2009), Macroprudential policy: what can it achieve?, 'Oxford Review of Economic Policy', 25(4). DOI: https://doi.org/10.1093/oxrep/grp036

Nier, E.W., Osinski, J., Jacome, L.I. \& Madrid, P. (2011), Towards effective macroprudential policy frameworks: An assessment of stylized institutional models, 'IMF Working Papers', No. 250, International Monetary Fund, Washington D.C.

Obstfeld, M. \& Rogoff, K. (2009), Global Imbalances and the Financial Crisis: Products of Common Causes, paper prepared for the Federal Reserve Bank of San Francisco Asia Economic Policy Conference, Santa Barbara, October 18-20, retrieved from: http://scholar.harvard.edu/ rogoff/publications/global-imbalances-and-financial-crisis-products-common-causes (20.03.2017).

Roubini, N., \& Mihm, S. (2010), Crisis Economics. A Crash Course in the Future of Finance, 'The Penguin Press', New York. 
Schinasi, G.J. (2010), Defining financial stability and establishing a framework to safeguard it, [in:] R.A. Alfaro (ed.). Financial stability, monetary policy, and central banking. Central Bank of Chile.

Taylor, J. (2009), Getting off track: How government action and interventions caused, prolonged, and worsened the financial crisis. Hoover Institution Press, Stanford.

Walsh, C.E. (2007), Optimal Economic Transparency, 'International Journal of Central Banking', Vol. 3, No. 1.

\section{Streszczenie}

\section{INSTYTUCJONALNE ROZWIĄZANIA W POLITYCE MAKROOSTROŻNOŚCIOWEJ - ANALIZA PORÓWNAWCZA W KRAJACH UNII EUROPEJSKIEJ}

Rośnie konsensus zarówno w gronie ekonomistów, jak i polityków, w odniesieniu do oceny funkcjonowania sieci bezpieczeństwa finansowego w okresie poprzedzajacym wybuch Globalnego Kryzysu Finansowego. Większość badaczy zgadza się co do kwestii brakujacego elementu tej sieci, którym jest makroostrożnościowa orientacja $w$ sprawowaniu nadzoru finansowego. Stą przedmiotem niniejszego artykułu jest polityka makroostrożnościowa, w szczególności zaś wymiar instytucjonalny tej polityki.

Głównym celem artykułu jest identyfikacja i ocena - na podstawie przeprowadzonych studiów porównawczych na próbie krajów Unii Europejskiej - istniejacych praktyk i kierunku rozwoju kształtu instytucjonalnego polityki makroostrożnościowej.

$W$ artykule wykorzystano zarówno aktualne, choć ograniczone ilościowo, rozważania natury teoretycznej, jak $i$ wyniki przeprowadzonych badań empirycznych $w$ odniesieniu do przyjętej struktury instytucjonalnej polityki makroostrożnościowej. W efekcie przeprowadzonego badania, zaproponowano zagregowana miare, pozwalajaca na ocene przyjętych rozwiazań instytucjonalnych w krajach UE (łacznie zidentyfikowano i oceniono 23 kryteria, będace podstawa porównania rozwiązań w zakresie odpowiedzialności demokratycznej, przejrzystości, stopnia koordynacji, jak i samej konstrukcji instytucji odpowiedzialnej za polityke makroostrożnościowa). Analiza porównawcza wartości mierników cząstkowych była podstawa weryfikacji zaproponowanych $w$ artykule hipotez $i$ stanowi empiryczna prezentację różnic $w$ funkcjonowaniu reżimów instytucjonalnych polityki makroostrożnościowej w krajach UE.

Wnioski zaprezentowane $w$ artykule stanowia przyczynek do oceny tendencji w zakresie jakościowych aspektów polityki makroostrożnościowej (przejrzystości i odpowiedzialności demokratycznej) i skali zróżnicowania rozwiąań instytucjonalnych tejże polityki w krajach Unii Europejskiej, w szczególności w odniesieniu do pozycji banku centralnego oraz stopnia sformalizowania przyjętych rozwiąań instytucjonalnych.

Słowa kluczowe: bankowość centralna, polityka makroostrożnościowa, ryzyko systemowe, stabilność finansowa 